\title{
Present Scenario of Online House Rental System in India and its Future Prospects
}

\author{
Pankaj Tiwari \\ Assistant Professor \\ Department of CSE, \\ S.I.E.T., AKTU
}

\author{
Harshit Gupta \\ Student, Department of \\ CSE \\ S.I.E.T, Allahabad
}

\author{
Ashwani Kumar \\ Student, Department of \\ CSE \\ S.I.E.T, Allahabad
}

\author{
Sudish Kumar Pandit \\ Student, Department of \\ CSE \\ S.I.E.T, Allahabad
}

\begin{abstract}
We are in an era where we are paving our way on the steps of technology and making our life simpler and effective and with this paradigm shift in technology we need to have a strategically push with technology. With this, one sector remains untouched and that is Housing (a way of managing online rental rooms). Thus, there is an urge to develop an online rental system that serves as a simplified and an efficient platform across various cities for both the rental managers and the tenants. One of the biggest challenges faced today is that everything is on paper that can quite expensive to store and record and gets damaged or lost easily.
\end{abstract}

\section{Keywords}

House, Rent, Tenant, Owner.

\section{INTRODUCTION}

India is developing country with approximately 132.42 crores and this figure is seemingly increasing year by year. In a survey report according to the census, there are still 1.77 million homeless people in India and there is still a shortage of about 18.78 million houses in India. Of all people living across the country only $11.1 \%$ people live in rented houses.

Table 1: Share of rental housing in urban and rural India

\begin{tabular}{|c|c|c|c|}
\hline & Total & Rural & Urban \\
\hline $\begin{array}{l}\text { Share of vacant houses in } 2001 \\
\text { (\% of all houses) }\end{array}$ & 6.3 & 5.3 & 9 \\
\hline $\begin{array}{l}\text { Share of vacant houses in } 2011 \\
\text { (\% of all houses) }\end{array}$ & 7.5 & 6.2 & 10.1 \\
\hline $\begin{array}{l}\text { \% Change in number of vacant } \\
\text { houses between } 2001 \\
\text { ans } 2011\end{array}$ & 56.3 & 44.7 & 70.8 \\
\hline
\end{tabular}

Source-: India's Residential Rental Housing, Arjun Kumar, EPW 2016

There more than 120 million rooms to be rented across the country including the metropolitan cities. People willing to take on rentals rooms have to comprise over quality, location of property, safety and comfort. Almost every room managers have a difficulty in getting screened tenant and managing their property and thus the market is fragmented and unharmonised, this is the problem. The main focus is basically managing rental housing for all the three income groups' i.e. low, medium and high income.
However, with growing urbanization, cities also become the areas of wealth accumulation, such that, there is competition for everything, including land. Under such circumstances, invading land and owning dwelling units become more and more difficult for the poor. With inadequate supply of land, other forms of tenure have risen. Rental housing is prominent among the cities, than at the overall country level. A country's economic and social stability lies in the hands of the people and housing strengthen the economic development. The key idea is to provide shelter to every single family or an individual depending upon their needs and financial capability and thus ascertain quality rental housing for everyone.

\section{CURRENT SCENARIO OF RENTAL HOUSING IN INDIA}

According to NSSO's (National Sample Survey Organization) in urban India about $30.4 \%$ people live in rented houses and about $3.4-5 \%$ people of rural India lives in rural area and this figure seems to be marginally increasing in the last few decades. The below figures show a rough estimate of rental housing in north and south India over the years.

There is very dramatic changes when we compare the above two maps of India.

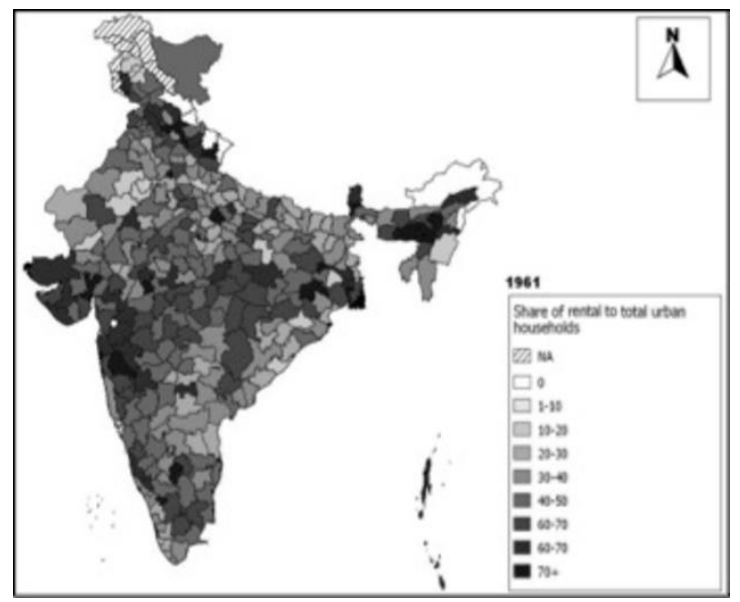

Figure 1(a): Urban rental housing in 1961 by district. 


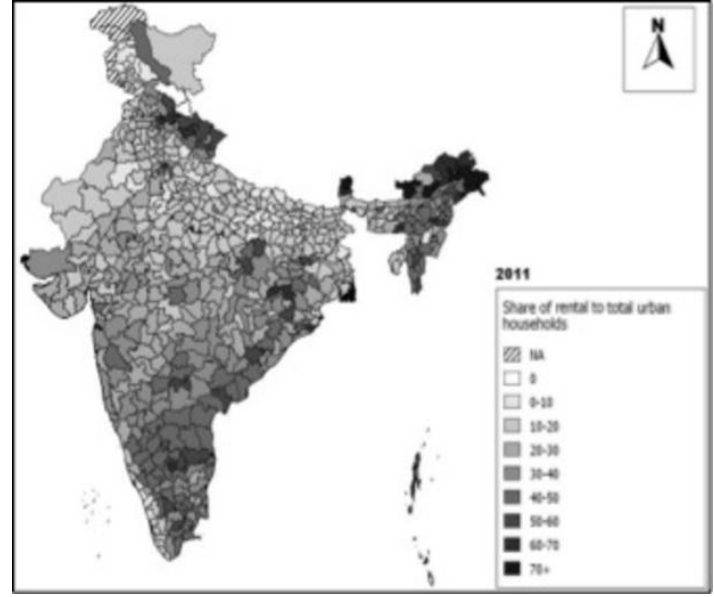

Figure 1(b): Urban rental housing in 2011 by district.

In 1961 there is huge demand of rental house as per census data, but by the passage of time these demand get decreased.

But the decrease is mainly north side of India, not in southern side. The information being given by census is not able to define the difference between this formal and informal rental housing.

As per the data of census the proportion of renting house in urban has fallen from 54 per cent to 33 per cent. The Figure shows the data about rental status, which based on district level.

If do more comparison on the basis of state wise, we can find that the Andhra Pradesh (47 per cent), Tamil Nadu(46.7 per cent), an d Karnataka (44.2 per cent) as top three states, in house rental..

The rental house has proportion of 30.4 per of all housing in india as per NSSO report in it's $65^{\text {th }}$ round of data of 200809 . And there was very less per cent of increase in house renting of urban india, from 28.1 per cent in 1993 to 29 per cent in 2002.

Table 2: Tenure Status of Dwelling Units in Urban India by States

\begin{tabular}{|l|l|l|l|}
\hline State & Owned & Rented & Others \\
\hline Andhra Pradesh & 40.9 & 47.0 & 12.1 \\
\hline Bihar & 78.5 & 13.0 & 8.5 \\
\hline Delhi & 51.7 & 36.4 & 11.8 \\
\hline Haryana & 73.7 & 20.7 & 5.7 \\
\hline Karnataka & 51.6 & 44.2 & 4.0 \\
\hline Kerala & 74.8 & 16.9 & 8.2 \\
\hline Madhaya Pradesh & 71.3 & 18.9 & 9.8 \\
\hline Tamil Nadu & 48.2 & 46.7 & 5.0 \\
\hline Uttar Pradesh & 75.3 & 18.8 & 5.9 \\
\hline Chandigarh & 42.7 & 30.4 & 8.0 \\
\hline
\end{tabular}

Source: NSSO (2010:58)

\section{ADVANTAGES [2]}

\subsection{Income from Renters}

It becomes a source of income for the renters.

\subsection{Huge investments are not required}

Renting allows you to live in a premium area that you might not be able to afford to buy.

It saves lots of investment.

\subsection{Immune to property price Fluctuations}

The frequent changes in property prices have negligible changes in rental prices.

\subsection{High Mobility}

In a rented accommodation one can almost always easily give a month's notice and vacate a house if he/she needs to change a home/locality/ city.

\subsection{Less responsibility}

The responsibility of the house is not completely on tenant.

Seepage, cracked floor, not working windows slider, etc. are responsibility of the owner.

\section{DISADVANTAGES [2]}

\subsection{Money}

Tenant will not get any benefits from the rent house, only the owner of the house will get the benefits.

\subsection{Renewing rental agreement}

Many states set rules on how much you can increase a current tenant's rent by.

\subsection{Maintenance issue}

Struggle to get the repairs done in a timely manner.

\subsection{Property restrictions or Personal Choices}

You can't decorate the home exactly as you'd like.

Landlords prohibit renters from painting walls and even driving nails into walls to hang décor.

No guests allowed.

\subsection{Equity}

When you own your own home, every house payment you make typically builds up a little more equity in your home. It's an investment, and over time, you own a greater and greater share of your home. When you rent a home, you get a place to live, but you don't own anything at the end.

Your rent simply pays for a roof over your head

\subsection{Living Environment}

When you own your own home, you have much greater control over your living environment. If a problem arises, you can fix it as quickly as you like, according to your own schedule. When you rent, the owner pays for repairs, which means he also controls who does the repairs and when. You might have to put up with an unlicensed handyman rather than a contractor, or the landlord might arrange for repairs at an inconvenient time. Some landlords are slow to make repairs, especially small ones that they don't consider important. For example, you might have to live with small inconveniences like squeaky doors and leaky faucets unless you fix them yourself.

\subsection{Instability}

Any infraction allows a landlord to remove you with a 30 day notice.

He can kick you out if he wants to sell the property. 


\section{FUTURE AND SCOPE}

With the increasing population across the country it becomes very difficult to provide home for everyone. According to the Census of India 2011, out of the 90 million residential census units, 11 million units are vacant; that is $12 \%$ of the total urban housing stock consists of vacant houses.

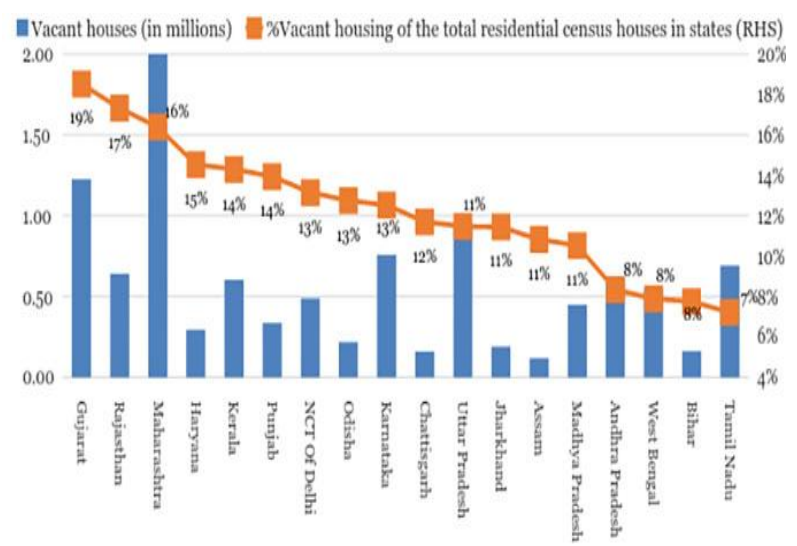

Figure 2. Vacant houses in major states.

Few factors bring an urge for online rental management. These are:

a) It's not easy to "build" millions of new houses congested households.

b) If the aim is to build millions of new housing units, clearly, lands is scarce.

Rental housing can be a significant proportion of housing supply. Rental yields (rent as a share of property price) are the returns a property owner can get on her investment and hence play an important part in deciding the economic viability of investing in rental housing. Rental yields in India are typically very low. As the number of land acquisition increases there are more and more household building being constructed with only one thing lacking i.e., proper ,management of these rentals so that every landlords can get a trusted tenant without the fear of evading rents and maintaining record of every tenant without the potential risk of losing these data.

\section{CONCLUSIONS}

Over the years, rental housing of total has fallen from $54 \%$ in 1961 to $28 \%$ in 2011 in urban India (Gandhi et al.2014). Without a vibrant rental housing management system labor markets cannot function efficiently. Argues that the recent financial crisis demonstrated that not everyone wants to, or can afford to, purchase a home, yet bias still remains against rental housing. By taking a systematic approach to rental housing and ensure a balanced approach to support future growth. Thus the main focus of the paper is to bring to highlight a proper online rental management system to offer services to the people and with one idea i.e., a safe home for all. With the increasing population this rental management system serves a basis for millions across the country and also will serve in the economic development of the country.

\section{ACKNOWLEDGEMENT}

Our heartily thanks to the project mentor Mr. Pankaj Tiwari, Assistant Professor, Department of CSE S.I.E.T (Allahabad) for being a constant source of help throughout the completion of this project.

\section{REFERENCES}

[1] Fig.1https://www.livemint.com/Opinion/a5jnMOHQs HEk47Rr9mUWPI/Five-charts-on-the-state-of-Indiashousing-sector.html

[2] http://maakan.com

[3] Fig.2. https://scroll.in/article/836589/housing-paradoxdespite-a-serve-shortage-12-of-houses-in0indiancities-are-lying-vacant.

[4] Mahadevia, Darshini (2011), "Rental Housing in Informal Settlements A Case-Study of Rajkot", pages (26-29) 